\title{
Design and build virtual tour panorama 360 Hospitality Center UNP as promotional media
}

\author{
Ika Parma Dewi ${ }^{1{ }^{1 *}}$, Agung Prasetyo ${ }^{2)}$, Muhammad Giatman ${ }^{3)}$, \\ Wakhinuddin $^{4)}$, Agariadne Dwinggo Samala ${ }^{5)}$ \\ 1)23)4)5))Universitas Negeri Padang, Padang, Indonesia \\ 1) ika_parma@ft.unp.ac.id, 2) agungprasetyotm@email.com, 3) giatman@ft.unp.ac.id \\ 4)wakhinuddins@gmail.com ${ }^{5)}$ agariadne@ ft.unp.ac.id,
}

Submitted : Oct 30, 2021 | Accepted : Dec 31, 2021 | Published : Jan 4, 2022

\begin{abstract}
The UNP Hospitality Center virtual tour application aims to help promote to potential visitors, and as an interactive promotional media. Hospitality Center UNP is an inn located in the Padang State University area and has various types of rooms and meeting facilities. Based on interviews with the UNP Hospitality Center internal parties, the promotions used are still using brochures. This tool only provides a little information to potential visitors about the rooms and facilities, namely only with photos and writing, this makes limited information that can be conveyed because with a brochure prospective visitors can only see one picture of each existing facility. The data collection stage was carried out by the method of interviews and direct observation. The next stage for developing the author's application uses the Multimedia Development Life Cycle (MLDC) method. consists of Concept, Design, Material Collecting, Assembly, Testing, and Distribution. The main features of this application are: hospitality profile, panorama list, location, floorplan and usage information. With these main features, it is found that by using the UNP Hospitality Center virtual tour application, it can make it easier to promote to prospective UNP Hospitality Center guests.

Keywords - virtual tour, Panorama, Hospitality Center UNP
\end{abstract}

\section{INTRODUCTION}

The development of existing technology is increasingly rapid, giving rise to many new innovations from technology, one of which is virtual tours, virtual tours using 360-degree images are currently widely used, one of which is for promotion. Virtual tour is a simulation of a location based on reality using 360 -degree panoramic photos (reality Photography). Virtual reality photography is processed in such a way that it allows users to interact directly with the virtual place. The characteristics of virtual reality photography, also called immersive photography or $360^{\circ}$ panoramic photos, are showing a location continuously (continuously), seamlessly and borderless in a $360^{\circ}$ viewing angle in the horizontal and or vertical directions (Ma,2011). virtual tour provides an overview of a place that is in accordance with the original (Navrotska,2013)

UNP Hospitality Center is a hotel development under the auspices of Padang State University where there is still a lack of information to the public about the UNP Hospitality Center. In promoting the Hospitality Center, UNP still uses brochures in conducting promotions, by using brochures, prospective visitors have limitations in knowing the facilities and forms of the Hospitality Center UNP itself, using a $360^{\circ}$ virtual tour can make it easier for prospective visitors to know how the facilities and forms of the Hospitality Center UNP. The virtual tour application as an information medium is said to be more efficient and attractive because virtual tours are more supportive compared to existing information media, both print and online media with limited information (Annafi,2014)

\section{LITERATURE REVIEW}

Promotion a form of marketing communication that seeks to disseminate information, persuade, and/or increase the market for the company and its products so that they are willing to accept and buy the products offered by the company concerned (Tjipto,2013). $360^{\circ}$ photos are the result of processing digital photos in the form of panoramas made by a camera system that simultaneously records the overall direction and $360^{\circ}$ rotation, using a $360^{\circ}$ camera to allow the user to shift and rotate the $360^{\circ}$ angle of view to see from a different perspective. different. Panoramic camera rotation, also called slit scan or 360 image scanning camera. scanning with a clockwise image

\footnotetext{
*name of corresponding author
} 
capture method or motorized mechanism rotates the camera continuously through the camera, resulting in photos with a wider field of view than ordinary photos with a range of 180-360 degrees, panoramas are usually created using the stitch method ("stitching" of several photo layers by combining pixels of the same value) (Zayid Musiafa,2020). Virtual tour is a technology that puts the user in the image and allows the user to significantly increase the visibility, capture and analysis of virtual data. The presentation of virtual tours can be done using images or videos, besides that, they can use 3-dimensional models. For presentation using images, 360-degree panoramic photos can be used. The end result, often called VR Panorama, can be viewed using an interactive interface application (it can rotate horizontally and vertically as if it were in the real world). This promotion can use Android mobile phones, where almost hotel visitors use this mobile operating system. The communication tool uses a gadget with the Android operating system. (IP Dewi,dkk. 2021)

\section{METHOD}

In this study, the application development methodology used is MDLC (Multimedia Development Life Cycle). This methodology has 6 stages, namely:

1. Concept

The concept stage is to formulate the basics of a multimedia project that will be created and developed. The concept stage determines the purpose and who is the user of the program (audience identification) the type of application, the purpose of the application

2. Design

Design is making specifications regarding program architecture, style, appearance and material/material requirements for the program. Manufacture of scripts or navigation and other design processes must be completed. This stage usually uses a storyboard to illustrate a description of each scene, listing all multimedia objects and links to other scenes and a flowchart to illustrate the flow from one scene to another.

3. Material Collecting

Material Collecting is the stage of collecting materials that are in accordance with the needs of the work, such as photos and icons. This stage can be done in parallel with the assembly stage

4. Assembly (Making Stage)

Assembly (Making Stage) is the stage of making all multimedia objects or materials. Making applications based on storyboards, flowcharts, and navigation structures from the design stage.

5. Testing

Testing (Trial Stage) is carried out after completing the manufacturing stage by running the application/program and seeing whether there are errors or not. The first stage at this stage is also known as the alpha testing stage, where the testing is carried out by the maker or the manufacturing environment itself. Software testing is very important because everyone makes mistakes when making software, errors in each software will be different.

6. Distribution

At this stage the application will be stored in a storage medium. This stage can also be called the evaluation stage for the development of finished products so that they become better. The results of this evaluation can be used as input for the concept stage of the next product.

It can be seen in Figure 1 that this methodology is very suitable because this methodology is used for the development of multimedia-based applications, because the 6 stages used can cover everything in the development of multimedia applications. If the data return is still lacking or damaged, this method provides an opportunity to retrieve data again. This can happen because this methodology allows the stages of data collection and creation to run together.

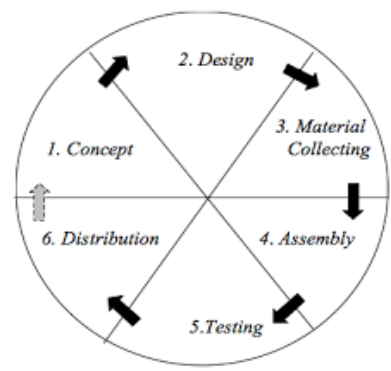

Figure 1. MDLC (Multimedia Development Life Cycle).

\section{A. Concept (conception),}

\footnotetext{
*name of corresponding author
} 
Formulate the basics of a multimedia project to be created and developed. The concept stage determines the purpose and who is the user of the application program, the purpose of the application, the output and input of the application. The concept of this research can be seen in table 1

Tabel 1. Konsep
\begin{tabular}{|c|l|}
\hline Title & $\begin{array}{l}\text { Design and Build Virtual Tour Panorama } 360 \text { Degree Hospitality Center Unp As } \\
\text { Promotional Media }\end{array}$ \\
\hline Aim & $\begin{array}{l}\text { 1) Generate UNP Hospitality Center promotions by using virtual tours. } \\
\text { 2) Generate virtual tours to display the facilities in the UNP Hospitality Center in detail } \\
\text { and in real terms. }\end{array}$ \\
$\begin{array}{c}\text { 3) Helping to facilitate Marketing in UNP Hospitality Center Promotion when you are } \\
\text { outside the area or when there is an event in another place. }\end{array}$ \\
\hline User & Potential visitors to the UNP Hospitality Center \\
\hline Virtual Object & UNP Hospitality Center Building (interior and Exterior) \\
\hline Input & Photos, text and audio \\
\hline Output & 360 degree photos, text and audio \\
\hline
\end{tabular}

\section{B. Design}

Design is making specifications regarding the program architecture, style, appearance and material requirements for the program, script creation or navigation of other design processes must be completed, this stage usually uses storyboards to describe a description of each scene, by including all multimedia objects and links to other scenes and flowcharts for developing flow from one scene to another.

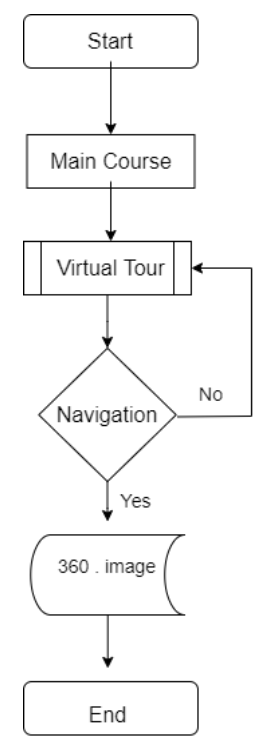

Figure 2: UNP Hospitality Center virtual tour flowcart

Flowchart is a picture that displays the structure, sequence of activities of a program from start to finish. 


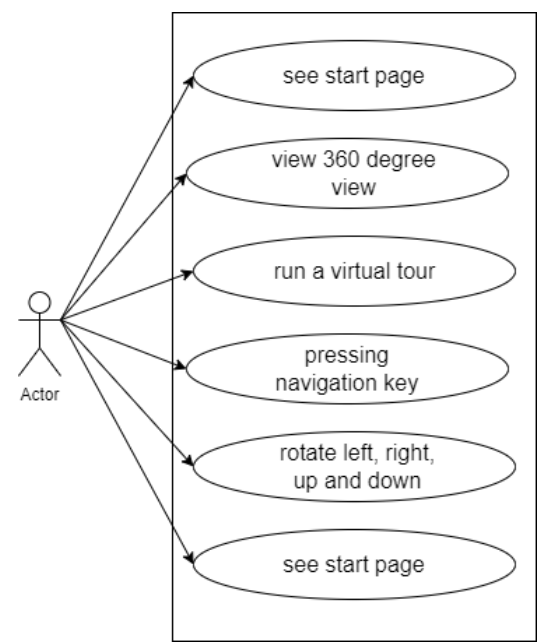

Figure 3: Use Case Diagram of a virtual tour application



Figure 4: Activity Diagram

Activity diagram of the UNP Hospitality Center virtual tour describes user activities using the features available in the application.

Table 2. Application Storyboard

\begin{tabular}{|c|l|l|}
\hline SCENE & VISUAL & DESCRIPTION \\
\hline 1 & $\begin{array}{l}\text { The initial menu display plan on the Virual } \\
\text { tour application, where the background uses } \\
\text { a building image from the UNP Hotel, and } \\
\text { there is a menu on the left. To enter the user } \\
\text { just click the arrow that appears. }\end{array}$ \\
\hline 2 & $\begin{array}{l}\text { The display of the stairs on the 1st floor, } \\
\text { next to the lobby, the user can click the } \\
\text { arrow that is visible to go to the next floor. }\end{array}$ \\
\hline
\end{tabular}




\begin{tabular}{|l|l|l|}
\hline SCENE & DISUAL & $\begin{array}{l}\text { DESCRIPTION display of the stairs goes down, to go } \\
\text { down to the next floor the user can click the } \\
\text { arrow. }\end{array}$ \\
\hline 3 & & $\begin{array}{l}\text { Auditorium door display, to enter the user } \\
\text { can click the icon on the door. }\end{array}$ \\
\hline 4 & $\begin{array}{l}\text { The audit view from the front, the user can } \\
\text { see the view 360 degrees. }\end{array}$ & $\begin{array}{l}\text { Arrow to the front of the IPC Corner room. } \\
\text { user can click the arrow to move. }\end{array}$ \\
\hline 6 &
\end{tabular}

C. Materials Collecting

1. Interview (interview)

Interviews were conducted in this study, namely by conducting questions and answers with the UNP Hospitality Center internal parties, to find out how far the promotions have been carried out and whether other forms of promotion are needed in promoting UNP Hospitality Centers.

2. Observation (Observation)

In this case, observations were made to find out the interior shape of the UNP Hospitality Center, and to see all the facilities in the UNP Hospitality Center.

\section{Assembly (Making Stage)}

\section{RESULT}

Assembly (Development Stage) is the stage of making all multimedia objects or materials, making applications based on storyboards, downstream charts (flowcarts), and navigation structures derived from the design. Furthermore, a 3D Vista application is needed to create a virtual tour application where the application will display a 360-degree panorama from each location, display control bar information, display information from each location, and display a map of the UNP Hospitality Center on Google Maps and users can get around virtually inside application with the help of a hotspot as a useful link to move to the next location.

1. 360 . shooting

The first step to create a virtual tour is to take 360-degree images using 360 images. Images can also be taken with a regular camera but to make them into 360 images you have to go through the stitching process.

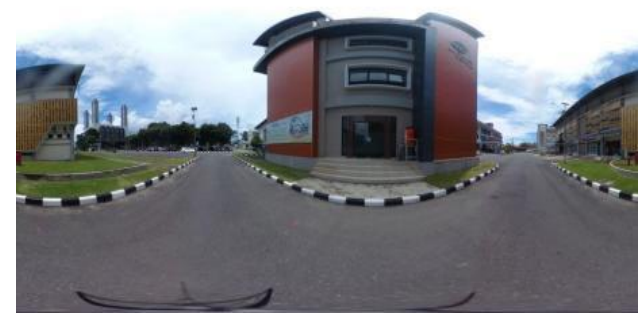

Figure 5: 360 Hospitality Shooting Process [source: Author's Document] 


\section{Start the project}

Based on the design that has been made in chapter III according to the data taken at the UNP hospitality center, where the UNP hospitality center consists of 4 floors, the 1st floor has a reception area, the 2nd floor has a restaurant and rooms, the 3rd floor is special for rooms and the 4th floor is special for meetings. rooms. After all the pictures are taken using a 360 camera, the next step is to combine the images to become a 360 virtual tour using the 3D Vista application.

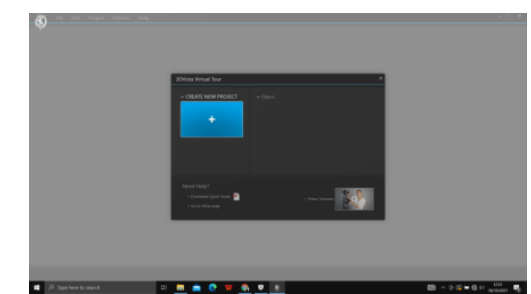

Figure 6: The Create New Project View [source: Author's Document]

The initial view of the 3D vista application, this is where a new project is created, when it is done, all you have to do is upload all the 360 images that have been taken before.

\section{Placing Hotspot}

After all the images are uploaded, the next step is to add a hotspot, a hotspot is useful for users to move from one place to another.

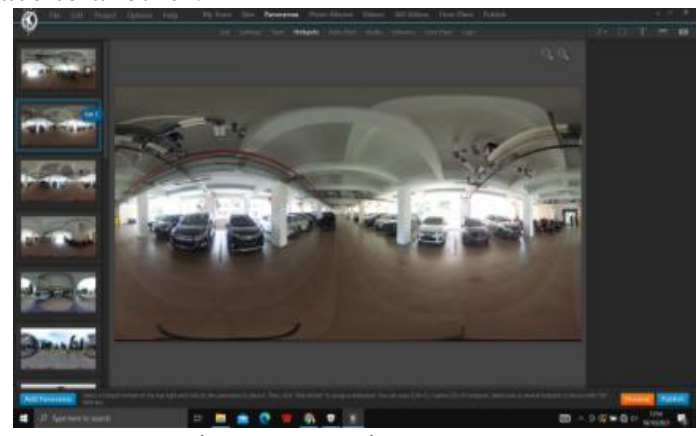

Figure 7: Laying Hotspot

[source: Author's Document]

\section{Interface}

After the manufacturing process, the interface results as shown in Figure 8.

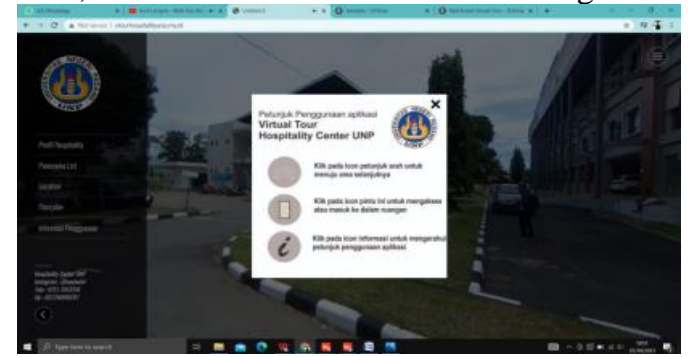

Figure 8: Virtual Tour Application Main Page

[source: Author's Document]

On the main page of the virtual tour application, it displays the Padang State University logo, a pop up image of application usage information, application opening audio, Hospitality Profile, Panorama List, Location, and Floorplan. 


\section{Testing}

\section{DISCUSSIONS}

Testing (Trial Stage) is carried out after completing the manufacturing stage by running the application/program and seeing whether there are errors or not. This test uses Black Box testing to find out the function of each attribute that is in the application running well before being distributed can be seen in table 3:

Table 3: BlackBox Test

\begin{tabular}{|c|c|c|c|}
\hline Feature & Expected Result & $\begin{array}{c}\text { Meet } \\
\text { Expectation }\end{array}$ & Comment \\
\hline Main Menu & $\begin{array}{l}\text { Initial screen where the user can see the } \\
\text { feature button and hear the application's } \\
\text { opening audio }\end{array}$ & Yes & \\
\hline $\begin{array}{l}\text { Button Profile } \\
\text { Hospitality }\end{array}$ & $\begin{array}{l}\text { users can see pictures of hospitality, } \\
\text { leadership and motto of Hospitality } \\
\text { Center UNP }\end{array}$ & Yes & $\begin{array}{l}\text { Can be developed so } \\
\text { that the photos used } \\
\text { are even more } \\
\text { interesting }\end{array}$ \\
\hline $\begin{array}{l}\text { Button } \\
\text { Panorama List }\end{array}$ & $\begin{array}{l}\text { user can see a list of panoramic images } \\
\text { used in the virtual tour }\end{array}$ & Yes & \\
\hline $\begin{array}{l}\text { Button } \\
\text { Location }\end{array}$ & $\begin{array}{l}\text { users can see the location of the UNP } \\
\text { Hospitality Center via Google map }\end{array}$ & Yes & \\
\hline $\begin{array}{l}\text { Button } \\
\text { Floorplan }\end{array}$ & $\begin{array}{l}\text { users can see the UNP Hospitality Center } \\
\text { plan from the 1st floor to the 4th floor }\end{array}$ & Yes & \\
\hline $\begin{array}{l}\text { Button } \\
\text { Informasi } \\
\text { Penggunaan }\end{array}$ & $\begin{array}{l}\text { user can see how to operate the virtual } \\
\text { tour application }\end{array}$ & Yes & \\
\hline Button Close & $\begin{array}{l}\text { the user can close the pop up image that } \\
\text { is displayed }\end{array}$ & Yes & \\
\hline $\begin{array}{l}\text { Audio } \\
\text { Penjelasan }\end{array}$ & $\begin{array}{l}\text { users can hear an audio explanation from } \\
\text { the room in the UNP Hospitality Center }\end{array}$ & Yes & $\begin{array}{l}\text { Audio giving can be } \\
\text { developed so that } \\
\text { every hotspot has au } \\
\text { audio }\end{array}$ \\
\hline $\begin{array}{l}\text { Button } \\
\text { Pengaturan }\end{array}$ & $\begin{array}{l}\text { user can set sound, fullscreen, turn off } \\
\text { Hotspot, open twitter and facebook }\end{array}$ & Yes & $\begin{array}{l}\text { Twitter and Facebook } \\
\text { can be developed to } \\
\text { lead to the UNP } \\
\text { Hospitality Center } \\
\text { account }\end{array}$ \\
\hline
\end{tabular}

The next test was an interview with Mrs. Mayang Puspita, as the manager of the UNP Hospitality Center about the results of the design and feasibility of the virtual tour. Based on interviews and tests that have been carried out by Ibuk Mayang Puspita, the results show that the virtual tour media is very helpful for the UNP Hospitality Center marketing team in promoting to prospective visitors because previously promotions at the UNP Hospitality Center used brochures, so using virtual tours made it easier to promote to candidates. visitors because by using a virtual tour prospective visitors can immediately feel the experience of being at the UNP Hospitality Center virtually, so that prospective visitors feel the facilities at the UNP Hospitality Center virtually. 
Further testing was also conducted with interviews with seniors in the multimedia field, who were asked to consider the interface and virtual tour content. Providing information to prospective visitors to the UNP Hospitality Center regarding the facilities provided, as if the potential visitors were at the UNP Hospitality Center, the interface displayed is also attractive and easily accessible by users.

Further testing was carried out with a questionnaire to the public, which was obtained from twenty questionnaires distributed, here are the data obtained from the questionnaire, which can be seen in the table:

Table 4: Qualitative classification by presentation

[Source: Suharsimi, Arkunto. 2012]

\begin{tabular}{|c|c|}
\hline Presentase & Category \\
\hline $80 \%-100 \%$ & Very high \\
\hline $60 \%-79 \%$ & Tall \\
\hline $40 \%-59 \%$ & Enough \\
\hline $20 \%-39 \%$ & Low \\
\hline$<20 \%$ & Very low \\
\hline
\end{tabular}

Table 5: Data from the questionnaire to the public [Source: Author's Document]

\begin{tabular}{|c|c|c|}
\hline No & Question & Results (\%) \\
\hline 1 & $\begin{array}{l}\text { Have you ever used a virtual tour service, either } 360 \text { degree Virtual } \\
\text { Tour or Live Video Virtual tour? }\end{array}$ & $80 \%$ \\
\hline 2 & Is the Virtual Tour application interface attractive? & $80 \%$ \\
\hline 3 & Are the functions of each button working properly? & $100 \%$ \\
\hline 4 & $\begin{array}{l}\text { The use of language in the audio explanation presented by the } \\
\text { presenter is clear }\end{array}$ & $80 \%$ \\
\hline 5 & $\begin{array}{l}\text { The audio message delivered by the presenter is short, concise and } \\
\text { clear. }\end{array}$ & $75 \%$ \\
\hline 6 & $\begin{array}{l}\text { Contents of explanatory audio according to the room/facility } \\
\text { described }\end{array}$ & $100 \%$ \\
\hline 7 & 360 images displayed clearly & $80 \%$ \\
\hline 8 & The legibility of the text on the virtual tour is clear & $80 \%$ \\
\hline 9 & The use of icons on virtual tours is easy to understand & $80 \%$ \\
\hline 10 & $\begin{array}{l}\text { Does this virtual tour help you in seeing the facilities provided by the } \\
\text { UNP Hospitality Center? }\end{array}$ & $90 \%$ \\
\hline
\end{tabular}

Based on testing through questionnaires conducted, the results show that the virtual tour application makes it easier for prospective visitors to see the facilities at the UNP Hospitality Center virtually, the interface that is displayed also makes it easier for users to use the application, explanatory audio also helps users find out information about the room being explored. users.

\section{CONCLUSION}

Based on the analysis of the design and implementation that has been done, the following conclusions can be drawn

1. UNP Hospitality Center virtual tour application to help promote to prospective visitors, UNP Hospitality Center virtual tour can be used as an interactive promotional media. 
2. The application of UNP Hospitality Center virtual tour technology as a promotional media in the form of 360 panoramic images makes it easier for potential visitors to know the facilities and locations of UNP Hospitality Center virtually.

\section{REFERENCES}

Adytio, A. (2017). Departemen Teknik Informatika. Pembuatan virtual tour Dengan Metode Gambar Panorama Untuk Kampus Fakultas Teknik Universitas Hasanuddin .

Alma, B. (2014). Manajemen Pemasaran dan Pemasaran Jasa. CV Alfabeta .

Daud, F. R., Tulena, V., \& Najoan, X. B. (2016). virtual tour Panorama 360 Derajat Kampus Universitas Sam Ratulangi Manado. Jurnal Teknik Informatika .

Dianta, A. F., Ekadarmawan, Z. M., Akbar, Z. F., \& Fathoni, K. (2021). Pengembangan Aplikasi Virtual Tour Sebagai Media Pengenalan Lingkungan Kampus Pens Berbasis Website. Jurnal Teknologi Terpadu, 24.

I.P.Dewi,dkk, (2021). Dasar-dasar Android Studio dan Membuat Aplikasi Mobile Sederhana . Bandung; Widina

Mardainis, Arifin, M., Rahmaddeni, \& Efendi, Y. (2020). virtual tour Interaktif 360 Derajat Menggunakan Teknik Image Stitching Sebagai Media Informasi Kampus STMIK Amik Riau. Digital Zone:Jurnal Teknologi Informasi \& Komunikasi .

Ngogoloy, B. R., Rindengan, Y. D., \& Sompie, S. R. (2018). virtual tour Instansi Pemerintahan Kabupaten Minahasa Tenggara. Jurnal Teknik IN=nformatika .

Ningrum, F. C., Suherman, D., Aryanti, S., Prasetya, H. A., \& Saifudin, A. (2019). Pengujian Black Box pada Aplikasi Sistem Seleksi sales Terbaik Menggunakan Teknik Equivalence Partitions. Jurnal Informatika Universitas Pamulung , 126.

Nur Budi, R. B., \& Wenas, M. B. (2018). Perancangan Virrtual Tour Kampus I UKSW Sebagai Media Informasi Mahasiswa Baru. Andharupa, 52-53.

Parma,dkk. (2021). Fotografi Digital Dengan DSLR . Lembar Langit Indonesia.

Syndicate, R. (2011). Fotografi Digital Dengan DSLR. Lembar Langit Indonesia.

Triani, A. R., Adriyanto, A. R., \& Faedhurrajman, D. (2018). Media Promosi Bisinis Potensi Wisata Daerah Bandung Dengan Aplikasi virtual Reality. Jurnal Bahasa Rupa .

Umafagur, F., Sentinuwo, S. R., \& Sugiarsa, B. A. (2016). Implementasi virtual tour Sebagai Media Informasi Daerah (Studi Kasus : Kota Manado). E-jurnla Teknik Informatika , 2-3.

Wijaya, A. H., \& Sufa'atin. (n.d.). Teknik Informatika-Universitas Komputer Indonesia. Pembangunan Aplikasi virtual tour Dan Reservasi Pada Avia Residence , 4.

Wulur, H. W., Sentinuwo, S., \& Sugiarso, B. (2015). Aplikasi virtual tour Tempat Wisata Alam Di Sulawesi Utara. E-jurnal teknik Informatika .

Yuliana, a., \& Lisdianto, E. (2017). Aplikasi Virtual Tour Sebagai Media Promosi Objek Wisata di Stone Garden Kabupaten Bandung Barat. KOPERTIP, 20. 